\title{
High prevalence of cytotoxin positive Helicobacter pylori in patients unrelated to the presence of peptic ulcers in Japan
}

K Ogura, F Kanai, S Maeda, H Yoshida, M Ogura, K-H Lan, K Hirota, T Kawabe, Y Shiratori, M Omata

\begin{abstract}
Background-It has been reported that infection with vacuolating cytotoxin positive Helicobacter pylori strains is associated with gastroduodenal disease in Western countries.

Aims-To evaluate the prevalence of cytotoxin producing strains among patients with $H$ pylori infection in relation to gastrointestinal diseases in Japan.

Patients-Ninety seven patients undergoing endoscopy.

Methods-A Western blot assay was conducted to detect serum antibodies against the cytotoxin using recombinant cytotoxin (VacA protein) as an antigen. To obtain a purified recombinant cytotoxin, the vacA gene (2233 nucleotides) was cloned into an expression vector to produce the protein (744 amino acids), which was expressed in Escherichia coli.

Results-Serum IgG antibodies to the cytotoxin were present in $85 \%, 95 \%, 95 \%$, and $100 \%$ of infected patients with gastric ulcer $(n=26)$, duodenal ulcer $(n=21)$, chronic gastritis $(n=19)$, and endoscopically normal mucosa $(n=14)$, respectively. Conclusion-The western blot method using recombinant VacA protein is simple and useful for detecting antibody to vacuolating cytotoxin. This method showed antibodies against cytotoxin were highly prevalent, even in subjects with endoscopically normal mucosa in Japan, indicating that the cytotoxin may not be an independent cause of gastrointestinal diseases induced by $H$ pylori infection.

(Gut 1997; 41: 463-468)
\end{abstract}

Keywords: stomach; Helicobacter pylori; vacA; ulcer; gastritis

Helicobacter pylori is a Gram negative bacterium which resides in the human stomach. The prevalence rate of its infection varies between countries, and a relatively high prevalence has been reported in Japan compared with other developed countries. ${ }^{12}$ Approximately $70 \%$ of the Japanese population aged over 40 is reported to be infected with the pathogen.

The infection is usually well tolerated with few symptoms, if any, in the majority of patients; nevertheless, it may play a significant role in the pathogenesis of peptic ulceration. This is highlighted by the reduction in the pep- tic ulcer relapse rate after successful eradication of this pathogen by antibiotics. ${ }^{3}$ However, the pathophysiological mechanisms for the different clinical diseases induced by $H$ pylori infection are not well understood. Several host factors, such as smoking, ${ }^{5-8}$ male sex, ${ }^{9}$ and blood type $\mathrm{O},{ }^{10}$ have been reported to predispose the host to the development of peptic ulceration.

Recent studies have suggested that differences in the virulence of $H$ pylori strains may influence the wide spectrum of gastrointestinal diseases. One of the claimed pathogenic bacterial factors is the $139 \mathrm{kDa}$ vacuolating cytotoxin, ${ }^{11}{ }^{12}$ known as the vac $A$ gene product. This cytotoxin has been reported to be produced by approximately $50 \%$ of $\mathrm{H}$ pylori strains isolated in Western countries, and has been found to be associated with peptic ulceration. ${ }^{13-18}$ Tee et $a l^{18}$ reported that the highest percentages of the strains producing cytotoxin were found in subjects with peptic ulcer disease (gastric ulcer, $65 \%$ of 20 patients; duodenal ulcer, $66 \%$ of 73 patients) compared with only $38 \%$ of those with non-ulcer dyspepsia (63 patients).

Antibodies in human sera against the vacuolating cytotoxin have often been assessed by using the neutralising assay. ${ }^{16} 19$ In Japan, Hirai et $a l^{20}$ reported a high prevalence of antibody $(100 \%)$ in sera of six patients with gastric carcinoma, using the antibody mediated neutralising assay against the cytotoxin, suggesting that there is a close relation between infection with cytotoxin producing strains and gastric cancer. The methodology of the neutralising assay, however, is too complicated for large scale analysis.

In order to assess the serum antivacuolating cytotoxin antibody which is thought to indicate infection with cytotoxin positive $H$ pylori strains, we have cloned the vacA gene, purified the recombinant cytotoxin protein expressed in Escherichia coli, and conducted a western blot assay to detect the antibody against the toxin in patients with and without various gastrointestinal diseases.

\section{Methods}

BACTERIAL STRAINS AND CULTURE CONDITIONS $H$ pylori strain ATCC (American Type Culture Collection) 43526, which is positive for vacuolating cytotoxin, was used to clone the vacA gene. $H$ pylori strain $\mathrm{Tx} 30 \mathrm{a}$, vacuolating cytotoxin negative strain (Tox-), ${ }^{21}$ was kindly
Accepted for publication 10 April 1997 


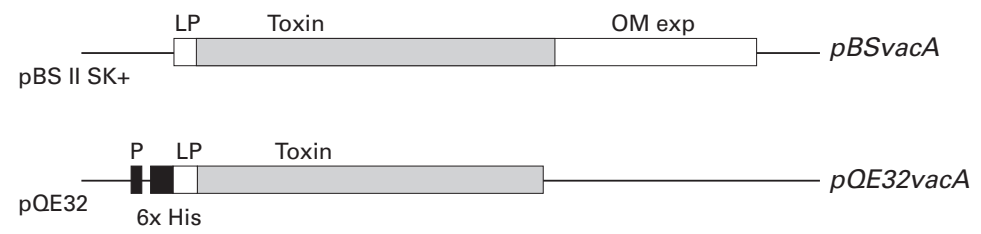

Figure 1: Schematic representation of plasmid constructs used for sequence analysis of the vacA gene and expression of cytotoxin protein in E coli. P, promoter; $6 \times \mathrm{His}$, histidine hexamer tag; LP, leader peptide; OM exp, outer membrane exporter.

provided by Dr JC Atherton (Vanderbilt University, Nashville, Tennessee, USA). $H$ pylori was cultured in Brucella broth culture medium (Becton Dickinson, Cockeysville, Maryland, USA) containing $10 \%$ fetal bovine serum (Cansera International Inc., Canada) in a microaerophilic atmosphere generated by CampyPak-Plus (Becton Dickinson) at $37^{\circ} \mathrm{C}$ for 48 hours. $E$ coli JM109 was used for the cloning experiments. Recombinant bacteria were grown in Luria-Bertani broth or agar plates containing ampicillin.

CLONING OF VACA GENE

$H$ pylori ATCC 43526 cells were cultured, harvested, and lysed in TNE (20 mM Tris- $\mathrm{HCl}$ (pH 7.5)/0.1 M NaCl/1 mM EDTA) buffer with $0.3 \%$ SDS and $0.2 \mathrm{mg} / \mathrm{ml}$ of proteinase $\mathrm{K}$ at $60^{\circ} \mathrm{C}$ overnight. The DNA was purified by phenol extraction, chloroform extraction, and precipitation with ethanol. Oligonucleotide primers with a PstI restriction site at the 5' terminus were designed to amplify the full length of the $v a c A$ gene open reading frame (ORF; $3864 \mathrm{bp})^{22}$ and used for polymerase chain reaction (PCR) amplification. Primer sequences were as follows: sense: 5'AGCTGCAGCATGGAAATACAACAAACACACCGCA-3' and antisense: 5'-AGCTGCAGCTTAGAAACTATACCTCATTCCTAAA-3'. PCR products (3891 bp), which contain the complete vacA gene ORF, were digested with PstI and cloned into the PstI site of pBluescript II SK (+) (Stratagene, La Jolla, California, USA), resulting in $\mathrm{pBSvacA}$ (fig 1). Nucleotide sequences of the insert were determined by the dideoxy chain termination procedure. $^{23}$

EXPRESSION AND PURIFICATION OF RECOMBINANT VACA PROTEIN

The $\mathrm{pBS} v a c A$ was digested with PstI and KpnI, and the $v a c A$ fragment encoding amino acids 1 to 744 was cloned in frame with the sequence coding for the histidine tag in the PstI-KpnI sites of pQE32 (Qiagen, Chatsworth, California, USA), resulting in pQE32vacA (fig 1). $E$ coli strain JM109 was transformed by pQE32vacA and recombinant protein was purified on Ni-nitrilotriacetic acid resin (Qiagen) as described by the manufacturer. Briefly, the recombinant protein was bound to the column in $6 \mathrm{M}$ guanidine hydrochloride $/ 0.1 \mathrm{M}$ sodium phosphate/0.01 M Tris $(\mathrm{pH} 8.0)$ and eluted with $8 \mathrm{M}$ urea/0.1 M sodium phosphate/0.01 M Tris (pH 5.9).

IMMUNISATION OF RABBITS

Antibodies were raised in rabbits against the recombinant VacA protein and a synthetic oli- gopeptide, VA-1. The VA-1 peptide, TSYKDSADRTTR (vacA residues 176-187 of $H$ pylori strain ATCC 43526), designed to have antigenicity, was synthesised according to the multiple antigen peptide (MAP) method $^{24}$ using the Shimadzu PSSM8 peptide synthesiser as described by the manufacturer. The amino acid sequences comprising the VA-1 peptide are conserved in Tox + strains. In Tx30a, a Tox- strain, vacA sequences (TSFKDGANRTTR) differ from the VA-1 peptide by three amino acids. The VA-1 peptide was used to obtain the antivacuolating cytotoxin antibody. New Zealand White rabbits, weighing approximately $2.5 \mathrm{~kg}$, were immunised by intradermal injections of $25 \mathrm{mg}$ purified recombinant VacA protein or $300 \mathrm{mg}$ VA-1. The rabbits were injected with a 1:1 emulsion of the antigen in complete Freund's adjuvant. Subsequently, three booster immunisations were performed every two weeks as a 1:1 emulsion in incomplete Freund's adjuvant. The antisera were collected two weeks after the last booster.

DETECTION OF VACA EXPRESSION OF H PYLORI ISOLATES BY WESTERN BLOT ASSAY

$H$ pylori culture supernatant was run on $10 \%$ SDS-polyacrylamide gels, and the proteins were transferred to nitrocellulose membranes by electroblotting. The membranes were then probed with antirecombinant vacA or antiVA-1 rabbit antisera and ${ }^{125}$ I-goat antirabbit IgG.

SOURCES OF HUMAN SERUM

Serum samples were obtained from 97 patients (64 men, 33 women; mean age 51.7 years) who underwent gastroduodenal endoscopy and were tested for $H$ pylori infection by culture, rapid urease test, and the PCR amplification of the urease gene (ureA) in gastric juice. ${ }^{25}$ No patient was taking non-steroidal antiinflammatory drugs. The sera were kept at $-20^{\circ} \mathrm{C}$ pending analysis.

\section{DETECTION OF SERUM IgG ANTIBODIES TO} H PYLORI

Serum samples were tested for the presence of antibodies against $H$ pylori by enzyme linked immunosorbent assay (ELISA), using a commercial kit, Helico G ELISA Kit (Porton Cambridge, Newmarket, UK), which detects the human anti- $H$ pylori IgG against total cell lysates of $H$ pylori.

WESTERN BLOT FOR DETECTION OF SERUM ANTIBODIES TO VACA

After separation by $10 \%$ SDS-PAGE, the recombinant vacA protein was transferred to a nitrocellulose membrane by electroblotting. The membrane strips were blocked with 3\% skimmed milk overnight, incubated with a $1 / 100$ dilution of the patient's serum, and shaken constantly at room temperature for two hours. After washing, protein bands were detected using the Vectastain ABC kit (Vector Laboratories Inc.), according to the manufacturer's instructions. 


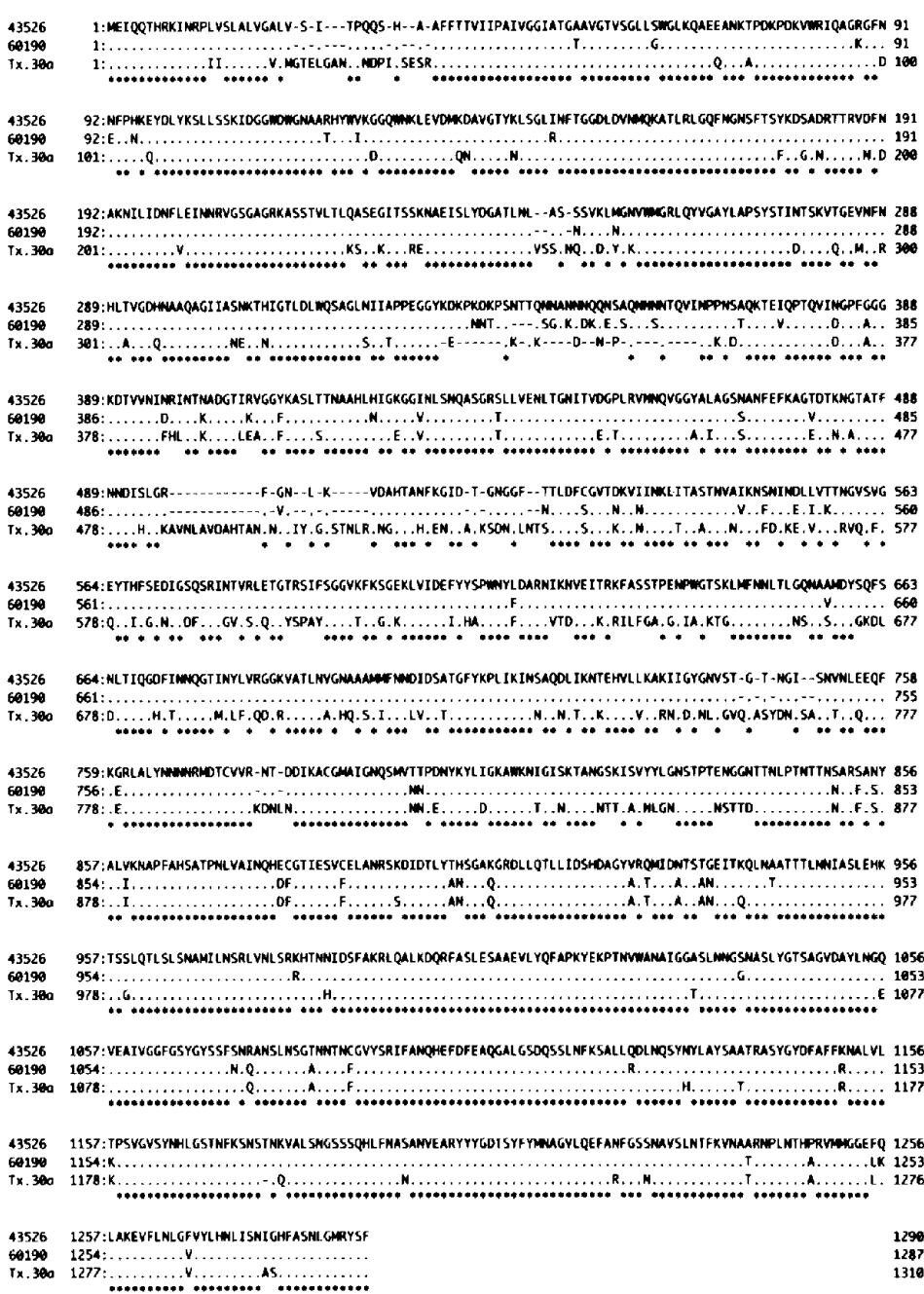

Figure 2: Alignment of the deduced VacA amino acid sequences between Tox+ strain 43526 (sequenced in this study), Tox+ strain 60190, and Tox- strain Tx30a. The 3873 bp vacA ORF encodes 1291 amino acids. Colons denote identity, and asterisks indicate conserved amino acids.

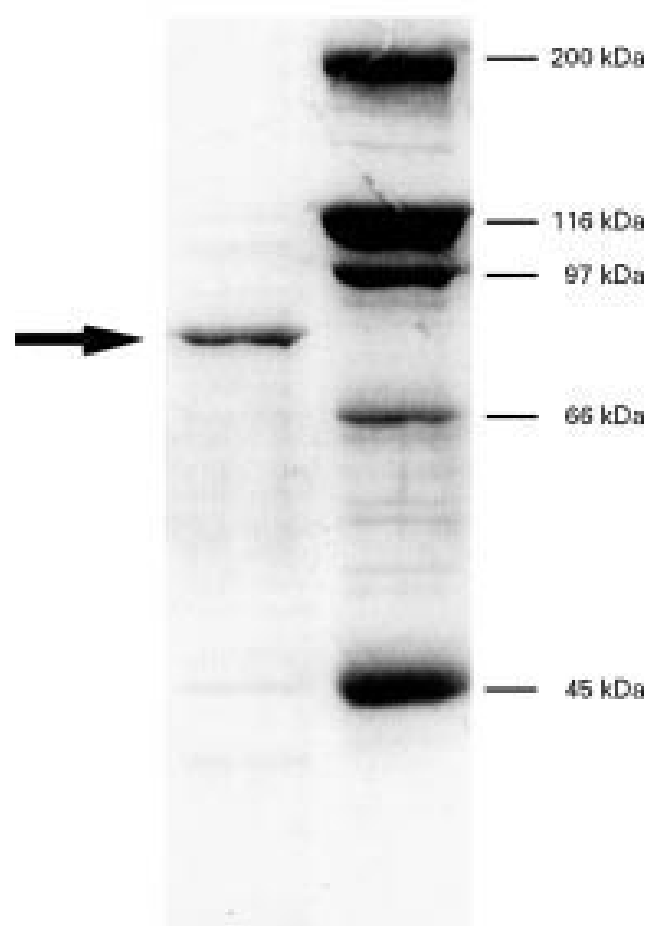

Figure 3: Expression of the vacA gene product in $E$ coli. SDS-PAGE with Coomassie brilliant blue staining shows the recombinant VacA protein with the expected molecular weight of about $80 \mathrm{kDa}$ (arrow). The migration of protein molecular mass standards is shown.

promoter (fig 1). This construction, pQE32vacA, was introduced into E coli JM109, and the expression of the toxin gene was induced by treatment with IPTG (isopropyl-bD-thiogalactopyranoside). To facilitate purification of the recombinant protein, it was expressed with six amino-terminal histidines (fig 1) which enable purification by nickel chelation chromatography. The recombinant protein was expressed in $E$ coli, and the purified protein showed a single band on SDS-PAGE (fig 3). The protein was purified in $8 \mathrm{M}$ urea, then dialysed stepwise for removal of urea. The protein was inactive in the vacuolation assay with HeLa cells both before and after dialysis (data not shown). H PYLORI STRAIN 43526

The entire vacA homologue from ATCC 43526, a vacuolating cytotoxin positive strain, was cloned (pBSvacA) (fig 1) and sequenced. A 3873 bp ORF was present, which encoded 1291 amino acids (fig 2). The predicted molecular weight of the cytotoxin was 138700 , which is similar to the size $(139-140 \mathrm{kDa})$ of vac $A$ products encoded by other strains. ${ }^{14}$ The amino acid sequences showed a similarity of $88-91 \%$ with those of cytotoxin positive strains described previously, ${ }^{22} 26-28$ but only $74 \%$ with that of the $\mathrm{Tx} 30$ a cytotoxin negative strain. ${ }^{21}$

\section{EXPRESSION OF VACUOLATING CYTOTOXIN IN} E COLI

From the plasmid pBSvacA containing the entire $H$ pylori vacA gene, the initial $2233 \mathrm{bp}$ of the gene was cloned into the plasmid vector pQE32 downstream of a synthetic inducible

\section{DETECTION OF VACA EXPRESSION BY H PYLORI}

ISOLATES

The presence of vacA proteins in the culture supernatant was tested by western blotting with the rabbit antisera against the recombinant VacA protein and VA-1. Antisera against the recombinant VacA protein recognised a band of approximately $87-94 \mathrm{kDa}$ that varied slightly in size between Tox + strain 43526 (fig 4, lane 3), Tox- strain Tx30a (lane 4), and Tox+ clinical isolates (lanes 6 and 7). The vacuolating cytotoxin was not present (lane 8) in the supernatant of the Tox-clinical isolate. Antisera against VA-1 recognised the cytotoxin in the cell lysate of strain 43526 at the same position as it was recognised by antirecombinant VacA protein sera (lane 5). 


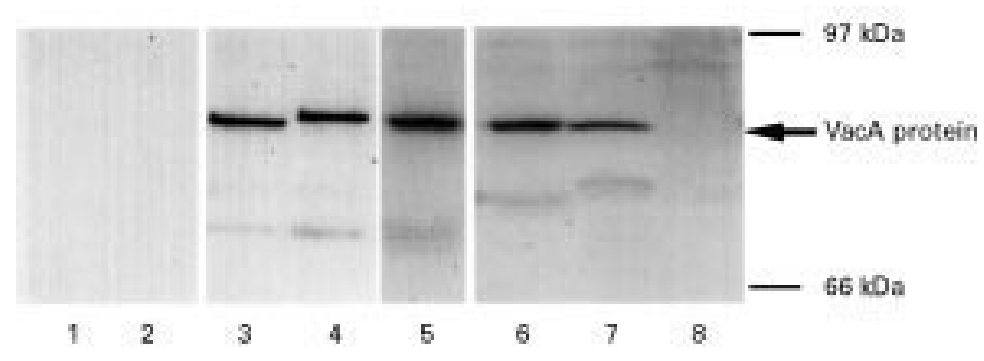

Figure 4: Western blotting analysis of VacA in H pylori. Culture supernatants from $H$ pylori strains were probed with control rabbit serum (lanes 1 and 2), rabbit serum raised against the recombinant VacA protein expressed in $E$ coli (lanes 3-4, 6-8), and rabbit serum raised against VA-1 (lane 5). The size variability of VacA protein in Tox strain 43526 (lanes 1, 3, and 5) or Tox-Tx30a (lanes 2 and 4) is shown. The position of protein molecular mass standards is indicated. H pylori clinical isolate culture supernatants were also blotted with antirecombinant VacA rabbit sera (lane 6, Tox+; lane 7, Tox+; lane 8, Tox-).

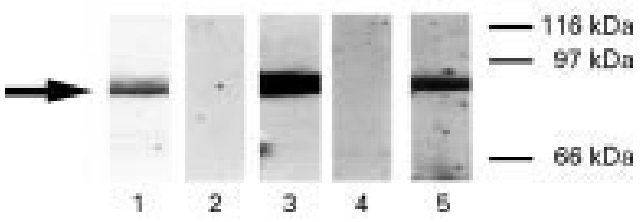

Figure 5: Western blotting with human sera or rabbit anti-VA-1 antiserum of the purified recombinant VacA protein. The recombinant VacA proteins were electrophoresed on $10 \%$ SDS-polyacrylamide gels, transferred to nitrocellulose membranes, and immunoblotted with human sera (lane 2, negative; lane 3, positive) or rabbit antiserum raised against VA-1 (lane 4, control; lane 5, immunised by VA-1). Gold staining of the cellulose membrane to which purified recombinant VacA protein was electroblotted is also shown (lane 1). The migration of protein molecular mass standards is indicated.

\section{DETECTION OF ANTI-VACA ANTIBODY IN HUMAN} SERA

Serum samples from 97 patients who had undergone endoscopy were examined by western blotting using recombinant VacA protein (fig 5). $H$ pylori infection was determined by conventional methods (culture and rapid urease test) on gastric biopsy specimens, serum anti- $H$ pylori IgG test, and PCR amplification of ureA gene in gastric juice. ${ }^{25}$ If more than two of the tests were positive, the patient was regarded as $H$ pylori positive. By this criterion, $H$ pylori infection was positive in 84 patients, and negative in 13. The serum anti-VacA antibody was positive in $77 / 84$ (92\%) $H$ pylori positive and $3 / 13(23 \%)$ negative patients (table 1). In the group of infected patients with gastric ulcer, duodenal ulcer, chronic gastritis, and endoscopically normal mucosa, the serum positive rate against vacA protein was $85 \%$ (22/26), 95\% (20/21), 95\% (18/19), and 100\% $(14 / 14)$, respectively (table 2$)$. There was no significant difference in the seropositivity among groups.

TABLE 1 Comparison of anti-recombinant VacA IgG antibody and H pylori infection diagnosed by culture, urease test, anti-H pylori antibody, or PCR methods in endoscoped patients

\begin{tabular}{lllcc}
\hline & \multicolumn{3}{l}{ Western blotting to recombinant VacA protein } \\
\cline { 3 - 5 } & & Positive & Negative & Total \\
\hline H pylori infection & Positive & 77 & 7 & 84 \\
& Negative & 3 & 10 & 13 \\
& Total & 80 & 17 & 97 \\
\hline
\end{tabular}

TABLE 2 Positive rates of anti-recombinant VacA antibody detected by western blotting in H pylori infected patients' sera

\begin{tabular}{llc}
\hline & $\begin{array}{l}\text { No (\%) of patients } \\
\text { positive for anti-VacA } \\
\text { antibody }\end{array}$ & \\
Diagnosis* & $22(84.6)$ & Total \\
\hline Gastric ulcer & $20(95.2)$ & 26 \\
Duodenal ulcer & $18(94.7)$ & 21 \\
Chronic gastritis & $14(100)$ & 19 \\
Endoscopically normal & $3(75.0)$ & 14 \\
Others† & $77(91.7)$ & 4 \\
Total & & 84 \\
\hline
\end{tabular}

^Patients were classified into five groups according to endoscopy findings.

†Including three patients with gastric cancer and a patient with gastric adenoma.

\section{Discussion}

The vacuolating cytotoxin is encoded by a $3864 \mathrm{bp}$ ORF in the vacA gene. ${ }^{22}$ The $137 \mathrm{kDa}$ $v a c A$ gene product consists of three regions: a 33 amino acid amino-terminal signal peptide, a mature cytotoxin domain of approximately $87 \mathrm{kDa}$, and a carboxy-terminal $50 \mathrm{kDa}$ segment which is cleaved from the molecule during transmembrane export. ${ }^{22} 27$ The recombinant protein described in this study predominantly covers the $87 \mathrm{kDa}$ domain.

Previous studies indicated that the vacuolating cytotoxin, which induces cellular vacuolation in a number of epithelial cell lines in vitro, is produced only by a subset of $H$ pylori isolates. ${ }^{11}{ }^{13}$ Furthermore, several studies suggested that infection by cytotoxin positive strains was correlated with the development of gastroduodenal diseases. ${ }^{129}$ Figura et $a l^{29}$ reported that $67 \%$ of $H$ pylori strains isolated from 24 patients with peptic ulcers produced cytotoxin, whereas only $30 \%$ of strains from 53 patients with chronic gastritis produced cytotoxin. Fox et $a l^{12}$ reported that the cytotoxin positive $H$ pylori strains were isolated from $69 \%$ of 26 patients with diffuse antral gastritis and $89 \%$ of 79 patients with chronic atrophic gastritis. However, their study groups were rather small in number. Further studies on large numbers of patients with and without gastrointestinal diseases are therefore needed.

Cytotoxicity assays, using culture supernatant and cell lines of previous studies, ${ }^{11}$ are essential but may not be suitable for the analysis of a large number of cases, since fresh biopsy specimens are necessary for bacterial culture. Several researchers have analysed cytotoxin neutralising activities using patient sera, which presumably represent neutralising antibodies against the toxin. ${ }^{16}{ }^{19}$ However, the specificity and sensitivity of this neutralising assay are not sufficient. For example, Pereira et $a l^{30}$ detected serum neutralisation in $17 / 21$ Tox + infected patients and in 9/41 Tox- infected patients. Hirai et $a l^{20}$ detected neutralising activity in 10/19 H pylori negative patients. Thus the neutralising method is not sufficient to elucidate the relation between vacuolating cytotoxin and gastroduodenal diseases in detail. Furthermore, the biological assay is complex and easily affected by many factors. We therefore tried to develop a simpler and more sensitive assay system.

In the present study, the $\operatorname{vac} A$ gene was cloned to produce a recombinant cytotoxin protein in large amounts. The recombinant 
protein was easily purified due to its histidine tag. ${ }^{31}$ Using this protein, antibodies which specifically react with the vacuolating cytotoxin in bacterial culture supernatant were successfully raised, demonstrating the intact immunogenicity of the recombinant cytotoxin. The size of the native cytotoxin, which reacted with the antibody against the recombinant cytotoxin, was the same as that which reacted with the antisera against VA-1, the antibody raised in rabbits. We suggest that both antibodies react with the native vacuolating cytotoxin. The recombinant and native cytotoxins are thus thought to have a common epitope. Using the recombinant protein, assessment of specific antibodies against the cytotoxin in patient sera was possible.

The recombinant protein purified in the present study failed to induce HeLa cell vacuolation in vitro, as reported previously. ${ }^{32}$ This may be due to the quaternary structure of active vacuolating cytotoxin, which is comprised of the multiple cytotoxin subunits, and failure of the recombinant cytotoxin to assemble correctly into an oligomeric structure. ${ }^{26}{ }^{32}$

The western blot assay using the purified recombinant vacuolating cytotoxin revealed the presence of antivacuolating cytotoxin antibodies in sera of the majority of patients with $H$ pylori infection, regardless of the type of gastroduodenal disease (peptic ulcer, chronic gastritis, and endoscopically normal mucosa). Chronic atrophic gastritis was observed endoscopically in $62 / 84$ (74\%) $H$ pylori positive patients and no relation was found between antivacuolating cytotoxin antibody and the presence of chronic atrophic gastritis. These results suggest that most strains of $H$ pylori in Japan produce the vacuolating cytotoxin in vivo, differing from previous results of others. ${ }^{11-13} 16-20$

There is a possibility that our results might differ from others due to use of different methods. The western blot method incorporating recombinant protein for detecting antibody to the cytotoxin may lack specificity. For example, antirecombinant VacA IgG antibody was observed in serum from $77 / 84(92 \%)$ infected patients (table 1) and this prevalence is higher than has been reported previously in other studies, which used different methods. Similarly, antibody was detected in 3/13 uninfected patients (table 1). In addition, the western blot procedure detects antibody against the "inactive" cytotoxin of strain Tx30a (fig 4) and the existence of inactive, but secreted cytotoxin was reported previously. ${ }^{2133}$ Each of these three items suggests at least the potential for poor specificity.

However, Xiang et $a l^{33}$ have reported that the protein is produced in only $2 / 16$ Tox $-H$ pylori strains, and Tox- strains which produce cytotoxin without vacuolating activity are believed to be uncommon. Thus, by serum anticytotoxin antibody analysis, the prevalence of cytotoxin positive strains may be estimated. In fact, most $H$ pylori isolates (34/38 strains) produce the active cytotoxin in vitro (unpublished observation), and vacuolation assay revealed that the majority of the strains have active cytotoxin in a subset of the patients in this study (data not shown). In addition, we have reported that the signal sequence of $v a c A$ gene is type $S 1$, indicative of Tox+ strains, in all $28 H$ pylori strains isolated from Japanese patients. $^{21}{ }^{34}$ These data may confirm the results in the present study.

Gastric cancer remains one of the most frequently diagnosed malignancies worldwide, and Japan has a high incidence of gastric malignancies, with 38.2 deaths per 100000 people in $1993 .{ }^{35}$ Epidemiological studies have demonstrated that the prevalence of $H$ pylori infection is significantly higher in patients with gastric cancer than in the general population. ${ }^{36}$ However, the mechanism by which $H$ pylori causes gastric cancer is not known. Our results showed that the majority of $H$ pylori strains from Japanese patients were positive for the vacuolating cytotoxin; it may therefore be conceivable that the high incidence of gastric cancer in Japan is related not only to the high prevalence of $H$ pylori infection but also to the high rate of cytotoxin producing strains in our country. A prospective large scale study using this western blot assay might reveal the relation between the incidence of gastric cancer and infection with cytotoxin positive $H$ pylori strains. Furthermore, other proteins produced by $H$ pylori should also be investigated-the size of the $H$ pylori genome suggests that it produces about 1700 proteins. $^{37}$

This work was supported in part by a grant from the Ministry of Education, Science, and Culture of Japan and by a Grant in Aid for Scientific Research from the Ministry of Education, Science, and Culture of Japan. F Kanai is a Research Fellow of the Japan Society for the Promotion of Science.

1 Asaka M, Kimura T, Kudo M, Takeda H, Mitani S, Miyazaki $\mathrm{T}$, et al. Relationship of Helicobacter pylori to serum pepsinogens in an asymptomatic Japanese population. Gastroenterology 1992; 102: 760-6.

2 Graham DY, Adam E, Klein PD, Evans DJ Jr, Evans DG, Hazell SL, et al. Epidemiology of Campylobacter pylori infection. Gastroenterol Clin Biol 1989; 13: 84-8B.

3 Marshall BJ, Goodwin CS, Warren JR, Murray R, Bloncow ED, Blackbourn SJ, et al. Prospective double-blind trial of $\mathrm{ED}$, Blackbourn SJ, et al. Prospective double-blind trial of
duodenal ulcer relapse after eradication of Campylobacter pylori. Lancet 1988; ii: 1437-42.

pylori. Lancet 1988; ii: 1437-42.
4 Hosking SW, Ling TKO, Chung SC, Yung MY, Cheng AF, Sung JJ, et al. Duodenal ulcer healing by eradication of Helicobacter pylori without anti-acid treatment: randomized controlled trial. Lancet 1994; 343: 508-10.

5 Breuer KB, Armstrong D, Goebell H, Arnold R, Classen M, Fisher M, et al. Smoking as a risk factor for duodenal ulcer relapse. RUDER Study Group. $Z$ Gastroenterol 1995; 33: 509-12.

6 Anda RF, Williamson DF, Escobedo LG, Remington PL. Smoking and the risk of peptic ulcer disease among women in the United States. Arch Intern Med 1990; 150: 1437-41.

7 Leoci C, Ierardi E, Chiloiro M, Piccioli E, Di matteo G, Misciagna G, et al. Incidence and risk factors of duodenal 1995; 20: 104-9.

8 Levenstein S, Prantera C, Varvo V, Scribano ML, Berto E, Spinella S, et al. Patterns of biologic and psychologic risk factors in duodenal ulcer patients. 7 Clin Gastroenterol 1995; 21: 110-7.

9 Sipponen P, Aarynen M, Kaariainen I, Kettunen P, Helske $\mathrm{T}$, Seppala K. Chronic antral gastritis, Lewis(a+) phenotype, and male sex as factors in predicting coexisting duodenal ulcer. Scand $\mathcal{F}$ Gastroenterol 1989; 24: 581-8.

10 Chuong JJ, Fisher RL, Chuong RL, Spiro HM. Duodenal ulcer. Incidence, risk factors, and predictive value of plasma pepsinogen. Dig Dis Sci 1986; 31: 1178-84.

11 Leunk RD, Johnson PT, David BC, Kraft WG, Morgan DR. Cytotoxic activity in broth-culture filtrates of Campylobacter pylori. $\mathcal{F}$ Med Microbiol 1988; 26: 93-9.

12 Fox JG, Correa P, Taylor NS, Thompson N, Fontham E, Janney $\mathrm{F}$, et al. High prevalence and persistence of cytotoxin-positive Helicobacter pylori strains in a population with high prevalence of

13 Cover TL, Dooley CP, Blaser MJ. Characterization of and human serologic response to proteins in Helicobacter 
pylori broth culture supernatants with vacuolizing cytotoxin activity. Infect Immun 1990; 58: 603-10.

14 Cover TL, Blaser MJ. Purification and characterization of the vacuolating toxin from Helicobacter pylori. $\mathcal{F}$ Biol Chem 1992; 267: 10570-5.

15 Ghiara P, Marchetti M, Blaser MJ, Tummuru MK, Cover TL, Segal ED, et al. Role of the Helicobacter pylor virulence factors vacuolating cytotoxin, $\mathrm{CagA}$, and urease in a mouse model of disease. Infect Immun 1995; 63: 415460 .

16 Leunk RD, Ferguson MA, Morgan DR, Low DE, Simor AE. Antibody to cytotoxin in infection by Helicobacter pylori. 7 Clin Microbiol 1990; 28: 1181-4

17 Leunk RD. Production of a cytotoxin by Helicobacter pylori. Rev Infect Dis 1991; 13: S686-9.

18 Tee W, Lambert JR, Dwyer B. Cytotoxin production by Helicobacter pylori from patients with upper gastrointestinal tract diseases. F Clin Microbiol 1995; 33: 1203-5.

19 Cover TL, Cao P, Murthy UK, Sipple MS, Blaser MJ. Serum neutralizing antibody response to the vacuolating Serum neutralizing antibody response to the vacuolating cytotoxin

20 Hirai M, Azuma T, Ito S, Kato T, Kohli Y, Fujiki N. High prevalence of neutralizing activity to Helicobacter pylori cytotoxin in serum of gastric-carcinoma patients. Int $\mathscr{f}$ Cancer 1994; 56: 56-60.

21 Atherton JC, Cao P, Peek RJ, Tummuru MK, Blaser MJ Cover TL. Mosaicism in vacuolating cytotoxin alleles of Helicobacter pylori. Association of specific vacA types with cytotoxin production and peptic ulceration. $f$ Biol Chem 1995; 270: 17771-7.

22 Cover TL, Tummuru MK, Cao P, Thompson SA, Blaser MJ. Divergence of genetic sequences for the vacuolating cytotoxin among Helicobacter pylori strains. $f$ Biol Chem 1994; 269: 10566-73.

23 Sanger F, Nicklen S, Coulson AR. DNA sequencing with chain-terminating inhibitors. Proc Natl Acad Sci USA 1977; 74: 5463-7.

24 Tam JP. Synthetic peptide vaccine design: synthesis and properties of a high-density multiple antigenic peptide sysproperties of a high-density multiple antigenic peptid
tem. Proc Natl Acad Sci USA 1988; 85: 5409-13.

25 Kawamata O, Yoshida H, Hirota K, Yoshida A, Kawaguchi $\mathrm{R}$, Shiratori Y, et al. Nested-polymerase chain reaction for the detection of Helicobacter pylori infection with nove primers designed by sequence analysis of urease A gene in clinically isolated bacterial strains. Biochem Biophys Res Commun 1996; 219: 266-72.

26 Phadnis SH, lver D, Janzon L, Normark S, Westblom TU. Pathological significance and molecular characterization of the vacuolating toxin gene of Helicobacter pylori. Infect Immun 1994; 62: 1557-65.

27 Schmitt W, Haas R. Genetic analysis of the Helicobacter pylori vacuolating cytotoxin: structural similarities with the IgA protease type of exported protein. Mol Microbiol 1994; 12: $307-19$.

28 Telford JL, Ghiara P, Dell'Orco M, Comanducci M, Burroni D, Bungnoli $\mathrm{M}$, et al. Gene structure of the Helicobacter pylori cytotoxin and evidence of its key role in gastric disease. F Exp Med 1994; 179: 1653-8.

29 Figura N, Guglielmetti P, Rossolini A, Barberi A, Cusi G, Musmanno RA, et al. Cytotoxin production by Campylobacter pylori strains isolated from patients with peptic bacter pylori strains isolated from patients with peptic
ulcers and from patients with chronic gastritis only. $\mathscr{f}$ Clin Microbiol 1989; 27: 225-6.

30 Pereira LA, Glupczynski Y, Goossens H, Burette A, Butzler JP. Neutralising antibodies to the vacuolating toxin of Helicobacter pylori in gastritis only and peptic ulcer patients. Int $\mathcal{F}$ Med Microbiol Virol Parasitol Infect Dis 1993; 280: 197202 .

31 Hochuli E, Dobeli H, Schacher A. New metal chelate adsorbent selective for proteins and peptides containing neighbouring histidine residues. $\mathcal{F}$ Chromatogr 1987; 411: $177-84$

32 Manetti R, Massari P, Burroni D, de Bernard D, Marchini A, Olivieri R, et al. Helicobacter pylori cytotoxin: importance of native conformation for induction of neutralizing antibodies. Infect Immun 1995; 63: 4476-80

33 Xiang Z, Censini S, Bayeli PF, Telford JL, Figura N, Rappuoli R, et al. Analysis of expression of CagA and VacA Rappuoli $\mathrm{R}$, et al. Analysis of expression of CagA and VacA
virulence factors in 43 strains of Helicobacter pylori reveals that clinical isolates can be divided into two major types and that CagA is not necessary for expression of the vacuolating cytotoxin. Infect Immun 1995; 63: 94-8.

34 Maeda S, Ogura K, Ishitobi M, Kanai F, Yoshida H, Ota S, et al. Diversity of Helicobacter pylori vacA gene in Japanese strains-high cytotoxin activity type $\mathrm{S} 1$ is dominant in Japan [abstract]. Gastroenterology 1996; 110: A182.

35 Health and Welfare Statistics Office. Table on mortality. Fournal of Health and Welfare Statistics 1995; 42: 404.

36 Parsonnet J, Friedman GD, Vandersteen DP, Chang Y, Vogelman $\mathrm{JH}$, Orentreich $\mathrm{N}$, et al. Helicobacter pylori infection and the risk of gastric carcinoma. $N$ Engl $\mathscr{f} M e d$ 1991; 325: 1127-31.

37 Fleischmann RD, Adams MD, White O, Clayton RA, Kirkness EF, Kerlavage AR, et al. Whole-genome random sequencing and assembly of Haemophilus influenzae Rd. Science 1995; 269: 496-512. 